Article

\title{
Preliminary Study: Purple Sweet Potato Extract Seems to Be Superior to Increase the Migration of Impaired Endothelial Progenitor Cells Compared to L-Ascorbic Acid
}

\author{
Yudi Her Oktaviono ${ }^{1, *}$, Makhyan Jibril Al-Farabi ${ }^{1,2}{ }^{\mathbb{D}}$, Luh Oliva Saraswati Suastika ${ }^{1}$, \\ Febriyanti Hartono ${ }^{1}$, Yanni Dirgantara ${ }^{3}$ and Ferry Sandra 4 \\ 1 Department of Cardiology and Vascular Medicine, Soetomo General Hospital, Faculty of Medicine, \\ Universitas Airlangga, Mayjend. Prof. Dr. Moestopo Street No. 6-8, 60286 Surabaya, Indonesia \\ 2 School of Management, Healthcare Entrepreneurship Division, University College London, Gower St, \\ Bloomsbury, WC1E 6BT London, UK \\ 3 Stem Cell Divison, Prodia Laboratory, Kramat 7 No. 11 Street, 10430 Jakarta, Indonesia \\ 4 Department of Biochemistry and Molecular Biology, Faculty of Dentistry, Universitas Trisakti, \\ Kyai Tapa Street No.260, 11440 Jakarta, Indonesia \\ * Correspondence: yudi.her@fk.unair.ac.id
}

Received: 9 May 2019; Accepted: 28 June 2019; Published: 3 July 2019

\begin{abstract}
Impairment of the endothelial progenitor cells (EPCs) ability to proliferate and migrate in the patients with coronary heart disease (CHD) is partly caused by oxidative stress. This research evaluates the effect of treatment with Ipomoea batatas L./purple sweet potato (PSP) extract and L-ascorbic acid on the proliferation and migration of impaired EPCs. EPCs were isolated from CHD patient's peripheral blood. EPCs culture were cultivated and divided into control (untreated), PSP extract treatment (dose 1 and $25 \mu \mathrm{g} / \mathrm{mL}$ ), and L-ascorbic acid treatment (dose 10 and $250 \mu \mathrm{g} / \mathrm{mL}$ ) groups for $48 \mathrm{~h}$. EPCs proliferation was analyzed with the 3-(4,5-dimethylthiazol-2-yl)-2,5-diphenyltetrazolium bromide (MTT) cell proliferation assay, and migration was evaluated with the cell migration assay kit. Statistical tests were evaluated using SPSS 25.0. This research showed that EPCs proliferation and migration was significantly higher in all PSP extract and L-ascorbic acid treatment compared to the control $(p<0.001)$. EPCs migration on treatment with a PSP extract dose of $25 \mu \mathrm{g} / \mathrm{mL}$ was significantly higher compared to the treatment with L-ascorbic acid dose of $250 \mu \mathrm{g} / \mathrm{mL}(303,000 \pm 1000$ compared to $215,000 \pm 3000$ cells, $p<0.001$ ). In conclusion, both treatments with PSP extract and L-ascorbic acid can improve the proliferation and migration of impaired EPCs. At the dose of $25 \mu \mathrm{g} / \mathrm{mL}$, PSP extract seems to be superior to the L-ascorbic acid dose of $250 \mu \mathrm{g} / \mathrm{mL}$ to improve EPCs migration.
\end{abstract}

Keywords: antioxidant; anthocyanin; coronary heart disease; functional

\section{Introduction}

Coronary heart disease (CHD) is responsible for around 33\% of death in individuals aged 35 and over in the World [1-3]. In Indonesia, the Ministry of Health reported that $12.9 \%$ of the mortality was caused by CHD [4]. Endothelial progenitor cells (EPCs) from the patients with CHD had reduced proliferation, and migration abilities, which can be worse as the disease progressed [5]. Impaired EPCs proliferation and migration capabilities can reduce its ability to repair vascular damage [5,6]. Patients with low EPCs count and impaired migration activity also have a higher incidence of cardiovascular events, mortality, and morbidity compared to patients with higher total EPCs and normal migration capabilities [7]. Multiple pathways were suggested to be responsible for EPCs impairment in CHD 
patients. It is suggested that oxidative stress plays significant roles in EPCs impairment through intracellular damage and balance disruption [8]. Disruption of the intracellular environment will alter the control of apoptosis, proliferation, self-renewal, senescence, and differentiation of EPCs, thus predisposing to the development of vascular pathology [9].

Previous studies showed that several antioxidants could improve EPCs growth and stem cells differentiation into EPCs [10,11]. Impaired proliferation of EPCs in cardiovascular-related disease was also able to be enhanced with antioxidant treatment $[12,13]$. As a prominent antioxidant, Vitamin $\mathrm{C}$ and $\mathrm{E}$ have been shown to prevent lowering the effect of TNF- $\alpha$ on EPCs proliferation through increased expression of phosphorylated p38 [14]. Plant-based extract with antioxidant properties such as Chokeberry (Aronia melanocarpa) [15], potato shoot (Solanum tuberosum) and Marigold (Calendula officinalis) extract were also proven to improve impaired EPCs proliferation and migration [16].

Various studies had demonstrated antioxidant properties of the Ipomoea batatas L./purple sweet potato (PSP) extract $[13,17,18]$. The major bioactive antioxidant constituents of PSP are anthocyanin [17] and $\beta$-carotene [18]. PSP extract has been shown to prevent endothelial dysfunction through inhibition of reactive oxygen species (ROS) and a nucleotide-binding domain (NOD)-like receptor protein 3 (NLRP3) signaling pathways [19]. It is also reported that the antioxidant capacity of PSP extract is quite similar to the prominent antioxidant, L-ascorbic acid [13]. While L-ascorbic acid has been proven to prevent the decrease of EPCs proliferation due to TNF $\alpha$ treatment via increase of phosphorylated-p38 and 5389 genes expression levels [14], no studies are showing the effect of both L-ascorbic acid and PSP extract on the impaired EPCs from CHD patients. In this study, we evaluated the effect of PSP extract and L-ascorbic acid toward proliferation, migration, and colony formation unit (CFU) of EPCs derived from CHD patients.

\section{Materials and Methods}

\subsection{PSP and $\mathrm{L}-$ Ascorbic Acid Preparation}

PSP was obtained from UPT Materia Medica Batu, Indonesia. PSP extract was produced with aqueous extraction method as described previously [20]. The L-ascorbic acid dose referred to previous research which use the L-ascorbic acid dose of $10 \mu \mathrm{g} / \mathrm{mL}$ to prevent lowering the effect of TNF $\alpha$ to EPCs proliferation [14] and dose of $250 \mu \mathrm{g} / \mathrm{mL}$ to improve adipocyte stem cells proliferation [21]. Briefly, PSP chunks were mixed in water with 1:1 ratio and blended. The mixture was filtered then boiled for $30 \mathrm{~min}$ and dried up using a rotary evaporator. The extract was then evaluated with the high-performance liquid chromatography (HPLC) analysis. Based on the HPLC analysis, PSP extract contained $146 \mu \mathrm{g} / \mathrm{mL}$ of anthocyanin. PSP extract was diluted with the culture medium to achieve a concentration of 1 and $25 \mu \mathrm{g} / \mathrm{mL}$. L-ascorbic acid powder (Sigma-Aldrich, St Louis, MO, USA) was suspended in double distilled water and diluted with culture medium to obtain a concentration of 10 and $250 \mu \mathrm{g} / \mathrm{mL}$.

\subsection{Subject Recruitment and Sample Collection}

The blood sample was obtained from eight CHD subjects in Dr. Soetomo General Hospital with inclusion criteria as follows: Male, aged 40-59, stable angina, and coronary angiography showed $>50 \%$ stenosis of left main coronary artery or $>70 \%$ of other coronary arteries. Subjects with the history of percutaneous coronary intervention, coronary artery bypass grafting, acute myocardial infarct, diabetes, smoking, and anemia were excluded. This study protocol was approved by the Health Research Ethics Committee of Dr. Soetomo General Hospital, Surabaya (No. 292/Panke.KKE/IV/2016, approved on 15 April 2016). Each subject has signed an informed consent before subject recruitment.

\subsection{EPCs Isolation and Culture}

Peripheral blood mononuclear cells (PBMCs) were isolated from the blood sample by Ficoll Histopaque 1077 (Sigma-Aldrich, St. Louis, MO, USA). To isolate EPCs from PBMCs, a standard 
protocol was conducted as described previously [22]. Briefly, $5 \times 10^{5}$ cells $/ \mathrm{mL}$ PBMCs were cultured in the fibronectin-coated 6-well plate with basal stemline II hematopoietic stem cell expansion medium (Sigma-Aldrich, St. Louis, MO, USA) supplemented with $15 \%$ fetal bovine serum and $40 \mathrm{ng} / \mathrm{mL}$ vascular endothelial growth factor. The culture was maintained at $37{ }^{\circ} \mathrm{C}$ with $5 \% \mathrm{CO}_{2}$ in a humidified atmosphere. Two days after, non-adherent cells were discarded, and fresh medium was added. Two weeks after, cultured cells were stained FITC-labeled anti-human CD34 antibody clone 581 (Biolegend, San Diego, CA, USA) and documented with an inverted immunofluorescence microscope. EPCs were confirmed from CD 34 expression.

\subsection{EPCs Proliferation Assay}

The MTT cell proliferation assay kit (Sigma-Aldrich, St Louis, MO, USA) was used to measure EPCs proliferation as described previously [12]. Treated EPCs were added with MTT reagent and incubated in a $37{ }^{\circ} \mathrm{C}$ incubator with $5 \% \mathrm{CO}_{2}$ for $4 \mathrm{~h}$. Proliferation was determined from the reduction of tetrazolium (MTT) into insoluble formazan product by viable EPCs mitochondria. Absorbance was measured with a microplate reader at $595 \mathrm{~nm}$ wavelength.

\subsection{EPCs Migration Assay}

The Boyden chamber assay method was used to calculate EPCs migration [15]. Isolated EPCs were detached using the Trypsin-EDTA solution (Sigma-Aldrich, St Louis, MO, USA). Then, $5 \times 10^{5}$ EPCs were seeded in the upper chamber with basal media. Meanwhile, basal media and chemoattractant were added in the lower chamber compartment with/without the addition of PSP extract or L-ascorbic acid. The culture was maintained for $24 \mathrm{~h}$ at $37^{\circ} \mathrm{C}$. Non-migratory EPCs, located on the upper chamber, were removed. After washing the upper chamber with PBS, the migrated EPCs, located below the upper chamber were fixed with $3.7 \%$ paraformaldehyde and permeabilized with methanol. Migrated EPCs were then stained with Giemsa and calculated.

\subsection{CFU Assay}

The CFU-Hill Liquid Medium Kit (Stemcell Technologies, Vancouver, BC, Canada) was used to measure CFU formation, as described previously [6]. Treated EPCs were cultured in 24-well plate wells with CFU-Hill colonies were calculated using an inverted light microscope. The colony with $\geq 15$ EPCs were counted as single CFU.

\subsection{Statistical Analysis}

Statistical analyses were performed using the IBM SPSS Statistics 25.0 (IBM Corp, Armonk, NY, USA). Data were considered significantly different if $p<0.05$. Data, presented as mean $\pm \mathrm{SD}$, were evaluated for distribution and compared using an appropriate test.

\section{Results}

\subsection{Demography of Subjects}

The blood samples were obtained from eight CHD subjects with the history of antihypertension and statin treatment. Demography of the subjects is shown in Table 1. 
Table 1. Demography of subjects.

\begin{tabular}{lc}
\hline \multicolumn{1}{c}{ Variable } & Mean \pm SD \\
\hline Age (year) & $54.5 \pm 4.31$ \\
Height $(\mathrm{cm})$ & $168.0 \pm 1.3$ \\
Weight $(\mathrm{kg})$ & $70.25 \pm 6.34$ \\
Body Mass Index $\left(\mathrm{kg} / \mathrm{m}^{2}\right)$ & $25.39 \pm 2.13$ \\
Systolic Blood Pressure $(\mathrm{mmHg})$ & $137.5 \pm 24.35$ \\
Diastolic Blood Pressure (mmHg) & $80.0 \pm 7.56$ \\
Heart Rate (beats/min) & $86 \pm 8.68$ \\
Total Cholesterol (mg/dL) & $200.5 \pm 74.75$ \\
Triglyceride (mg/dL) & $97 \pm 11.64$ \\
Low-density lipoprotein (LDL) (mg/dL) & $145 \pm 61.11$ \\
High-density lipoprotein (HDL) (mg/dL) & $35 \pm 7.64$ \\
Left Ventricle Ejection Fraction $(\%)$ & $53.5 \pm 4.11$ \\
\hline
\end{tabular}

\subsection{PSP Extract and $\mathrm{L}-$ Ascorbic Acid Increased EPCs Numbers}

As shown in Figure 1, under the treatment of PSP extract and L-ascorbic acid at all doses, the number of EPCs was significantly higher than the untreated EPCs $(p<0.001$, ANOVA). The $25 \mu \mathrm{g} / \mathrm{mL}$ PSP extract-treated EPCs number was significantly higher than the $1 \mu \mathrm{g} / \mathrm{mL}$ PSP extract-treated EPCs number $(p<0.001, t$-test). However, no significant difference was observed on the EPCs number between treatment with PSP extract dose of $1 \mu \mathrm{g} / \mathrm{mL}$ and L-ascorbic acid dose $10 \mu \mathrm{g} / \mathrm{mL}$ ( $p=0.418$, $t$-test). Comparison between $25 \mu \mathrm{g} / \mathrm{mL}$ PSP extract-treated and $250 \mu \mathrm{g} / \mathrm{mL}$ L-ascorbic-treated EPCs numbers also showed no significant differences.

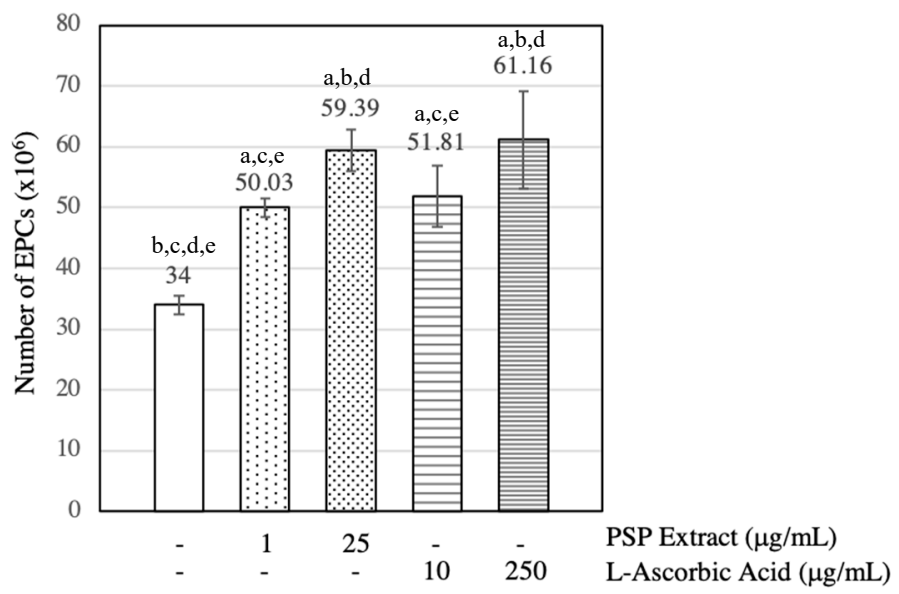

Figure 1. Purple sweet potato (PSP) extract and L-ascorbic acid induced endothelial progenitor cells (EPCs) numbers. EPCs were treated with/without $1 \mu \mathrm{g} / \mathrm{mL}$ PSP extract, $25 \mu \mathrm{g} / \mathrm{mL}$ PSP extract, $10 \mu \mathrm{g} / \mathrm{mL}$ L-ascorbic acid or $250 \mu \mathrm{g} / \mathrm{mL}$ L-ascorbic acid for $48 \mathrm{~h}$. Viable EPCs were counted using MTT (3-[4,5-dimethylthiazole-2-yl]-2,5-diphenyltetrazolium bromide) proliferation assay and statistically analyzed, as described in Materials and Methods. Sextuplicate was performed for each group. a: Significant difference compared to the untreated group $(p<0.001)$, b: Significant difference compared to the $1 \mu \mathrm{g} / \mathrm{mL}$ PSP extract-treated group $(p<0.001)$, c: Significant difference compared to the $25 \mu \mathrm{g} / \mathrm{mL}$ PSP extract-treated group $(p<0.001)$, d: Significant difference compared to the $10 \mu \mathrm{g} / \mathrm{mL}$-ascorbic-treated group $(p<0.001)$ and e: Significant difference compared to the $250 \mu \mathrm{g} / \mathrm{mL}$ L-ascorbic acid-treated group $(p<0.001)$.

\subsection{PSP Extract and L-Ascorbic Acid Induced EPCs Migration}

As shown in Figure 2, under the treatment of PSP extract and L-ascorbic acid at all doses, the number of EPCs was significantly higher than the untreated EPCs $(p<0.001$, ANOVA). In the current study, the highest number of migrated EPCs was seen on the treatment with $25 \mu \mathrm{g} / \mathrm{mL}$ PSP extract. 


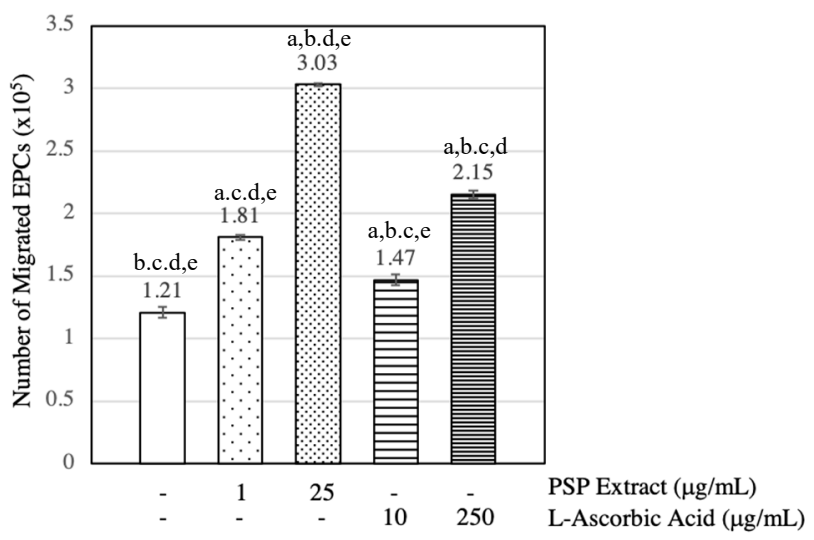

Figure 2. PSP extract and L-ascorbic acid induced EPCs migration. EPCs were cultured in Boyden chambers as described in Materials and Methods, EPCs were induced with/without $1 \mu \mathrm{g} / \mathrm{mL}$ PSP extract, $25 \mu \mathrm{g} / \mathrm{mL}$ PSP extract, $10 \mu \mathrm{g} / \mathrm{mL}$ L-ascorbic acid or $250 \mu \mathrm{g} / \mathrm{mL}$ L-ascorbic acid for $48 \mathrm{~h}$. Sextuplicate was performed for each group. a: Significant difference compared to the untreated group $(p<0.001), \mathrm{b}$ : Significant difference compared to the $1 \mu \mathrm{g} / \mathrm{mL}$ PSP extract group $(p<0.001)$, c: Significant difference compared to the $25 \mu \mathrm{g} / \mathrm{mL}$ PSP extract group $(p<0.001)$, d: Significant difference compared to the $10 \mu \mathrm{g} / \mathrm{mL}$ L-ascorbic acid group $(p<0.001)$ and e: Significant difference compared to the $250 \mu \mathrm{g} / \mathrm{mL}$ L-ascorbic acid group $(p<0.001)$.

\subsection{PSP Extract and $\mathrm{L}-$ Ascorbic Acid Induced EPCS CFU Formation}

As shown in Figure 3, the PSP extract seems superior to induce CFU formation compared to the L-ascorbic acid. The highest number of CFUs was induced by treatment of $25 \mu \mathrm{g} / \mathrm{mL}$ PSP extract. The $250 \mu \mathrm{g} / \mathrm{mL}$ L-ascorbic acid induced the CFU formation as well. However, treatment with $10 \mu \mathrm{g} / \mathrm{mL}$ L-ascorbic acid did not induce the CFU formation and have a lower number of CFUs compared to the one untreated with PSP extract/L-ascorbic. CFUs morphology was observed and shown in Figure 4.

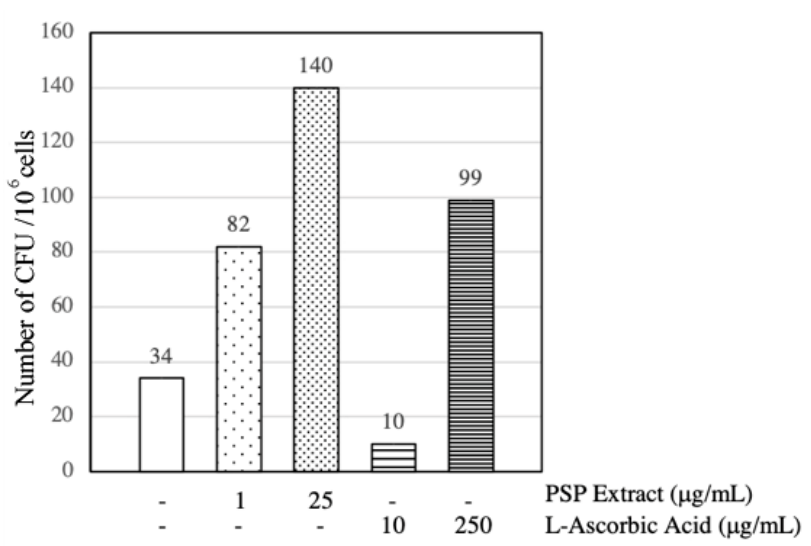

Figure 3. Effect of the PSP extract and L-ascorbic acid in inducing colony formation units (CFUs) formation. EPCs were cultured in CFU-Hill Liquid Medium Kit as described in Materials and Methods. The culture was treated with/without $1 \mu \mathrm{g} / \mathrm{mL}$ PSP extract, $25 \mu \mathrm{g} / \mathrm{mL}$ PSP extract, $10 \mu \mathrm{g} / \mathrm{mL}$ L-ascorbic acid or $250 \mu \mathrm{g} / \mathrm{mL}$ L-ascorbic acid for $48 \mathrm{~h}$. The colony with $\geq 15$ EPCs were counted as a CFU. 


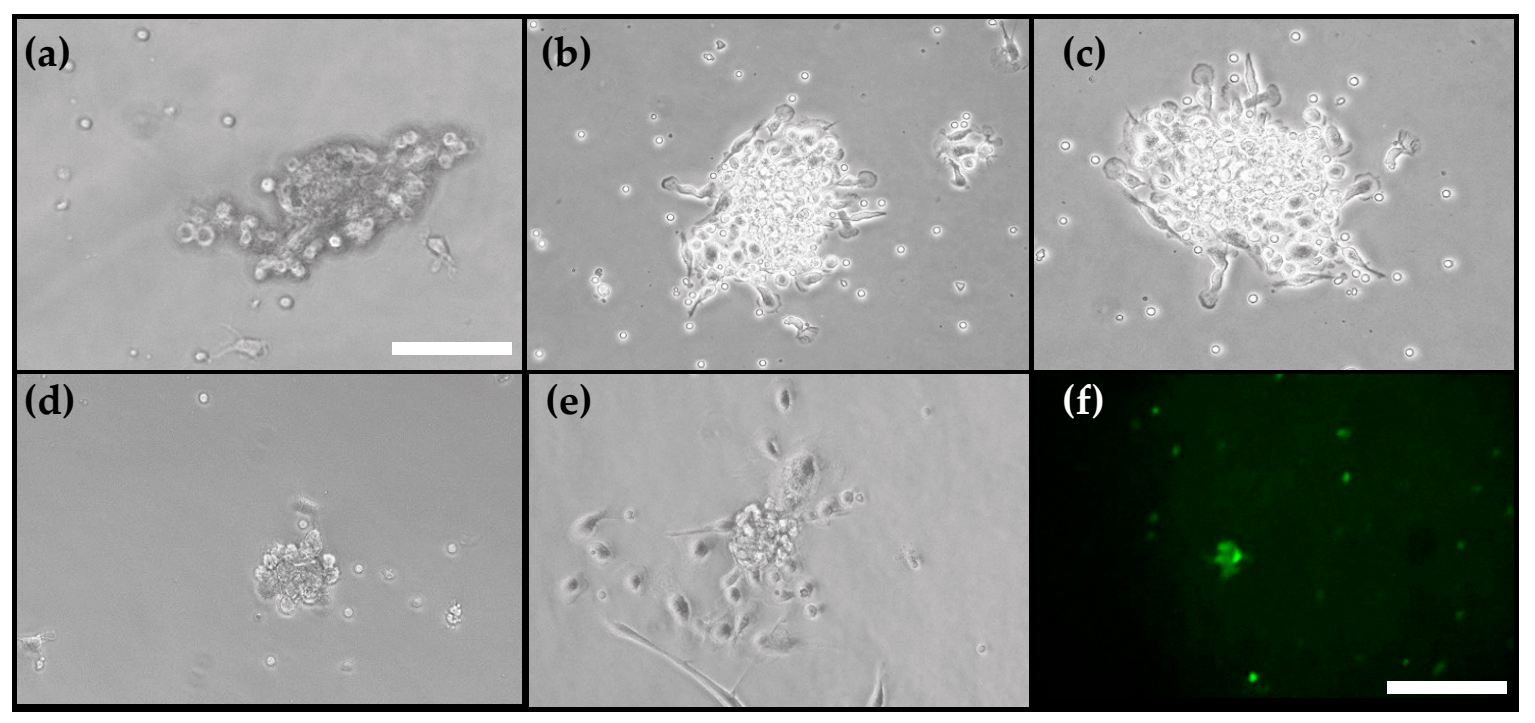

Figure 4. Morphology of CFUs. Light-inverted microscope view of EPCs under 100× magnification after 48 h-treatment of negative control (untreated) (a), $1 \mu \mathrm{g} / \mathrm{mL}$ PSP extract (b), $25 \mu \mathrm{g} / \mathrm{mL}$ PSP extract (c), $10 \mu \mathrm{g} / \mathrm{mL}$ L-ascorbic acid (d), and $250 \mu \mathrm{g} / \mathrm{mL}$ L-ascorbic acid (e). (f) FITC-labelled CD34 immunofluorescence expression of EPCs. White bar represent $100 \mu \mathrm{m}$.

\section{Discussion}

EPCs proliferation, migration, and differentiation are severely impaired in patients with CHD [5]. This research showed that L-ascorbic acid dose of 10 and $250 \mu \mathrm{g} / \mathrm{mL}$ had beneficial effects to improve the proliferation and migration of the EPCs derived from the peripheral blood of CHD patients in a concentration-dependent manner. Similar with this finding, the previous study showed that exogenously supplemented $250 \mu \mathrm{g} / \mathrm{mL} \mathrm{L}$-ascorbic acid also improves the proliferation of adipocyte stem cells [21], cardiac progenitor cells [23] and intestinal stem cells [24]. Meanwhile, in the EPCs, in vitro incubation with L-ascorbic acid at dose $10 \mu \mathrm{g} / \mathrm{mL}$ can revert the lowering effect of TNF- $\alpha$ on EPCs number through inhibition of p38 expression [14]. Suggesting that L-ascorbic acid may be a potential candidate to improve impaired EPCs in CHD patients. However, this research also showed that L-ascorbic acid was only able to improve CFUs number at the dose of $250 \mu \mathrm{g} / \mathrm{mL}$. Suggesting that to achieve improvement of proliferation, migration, and differentiation from impaired EPCs, a higher dose of $\mathrm{L}$-ascorbic acid is required.

In this research, it was shown that the PSP extract dose of 1 and $25 \mu \mathrm{g} / \mathrm{mL}$ have beneficial effects to improve the proliferation, migration, and differentiation of impaired EPCs. As the PSP extract main constituent was anthocyanins, previous research also showed that pure anthocyanin treatment was able to improve the migration and proliferation of impaired EPCs in vivo [25]. Another plant-based extract which contains a high-level of anthocyanin such as Aronia melanocarpa fruit extract has been proven to reduce intracellular ROS formation and increase the proliferative activity of EPCs in a dose-dependent manner [15]. This suggested that the anthocyanin from PSP extract may be responsible for its beneficial effect on the proliferation, migration, and differentiation of impaired EPCs.

While the exact mechanism of the EPCs impairment in CHD patients remained unclear, it is suggested that oxidative stress from ROS can induce cellular damage and disrupt the intracellular balance, which impairs EPCs function to migrate and proliferate [8]. Some antioxidants such as resveratrol, vitamin E, and L-arginine has been proven to increase EPCs number and functional activities in vitro and in vivo [14,25]. In this research, we used L-ascorbic acid and PSP extract, which has been shown to have antioxidant properties [17] and both treatments have been shown to improve the impaired EPCs proliferation and migration capabilities

In the EPCs, ROS can cause endothelial nitric oxide (NO) synthase (eNOS) uncoupling and therefore increased oxidative stress and impaired NO bioavailability [26]. Increased intracellular 
NO in the EPCs, may change the cytoskeleton and gene transcription, leading to enhanced EPCs migration capacity [26]. Hence, a higher reduction of free radical through scavenging activities of antioxidant may help EPCs maintain intracellular NO balance, thus improving its migration capabilities. However, as this research did not evaluate each treatment antioxidant capacities and intracellular $\mathrm{NO}$, further validation should be pursued to verify this pathway and its involvement in the EPCs functional improvement.

Compared to L-ascorbic acid, our results showed that the PSP extract was more potent in inducing EPCs proliferation since the lower concentration of the PSP extract $(25 \mu \mathrm{g} / \mathrm{mL})$ had the same effectivity with a higher dose of L-ascorbic acid $(250 \mu \mathrm{g} / \mathrm{mL})$. In the improvement of EPCs migration and differentiation capabilities, the PSP extract was superior compared to L-ascorbic acid, since the lower concentration of the PSP extract $(25 \mu \mathrm{g} / \mathrm{mL})$ had higher effectivity compared to a higher dose of L-ascorbic acid $(250 \mu \mathrm{g} / \mathrm{mL})$. As we hypothesize that antioxidant mechanism might be responsible for this effect, higher antioxidant capabilities of PSP extract compared to L-ascorbic acid may explain the superiority of the PSP extract. Similar superiority of the PSP extract compared to L-ascorbic acid was also observed in the previous research which showed at a similar dose of $50 \mu \mathrm{g} / \mathrm{mL}$, PSP has $70 \%$ superoxide scavenging activity while L-ascorbic acid only has 13\% [27]. Despite these findings and comparison, further research should be pursued to evaluate the direct association between antioxidant capabilities of L-ascorbic acid and PSP extract with the functional improvement of EPCs.

\section{Conclusions}

Treatment of PSP extract and L-ascorbic acid can improve the proliferation, migration, and differentiation of impaired EPCs from CHD patients. The PSP extract seems to be superior to L-ascorbic acid to mainly improve impaired EPCs migrational capabilities. Hence, the PSP extract may become a supplementary candidate to improve impaired EPCs in CHD patients.

Author Contributions: Conceptualization, Y.H.O., L.O.S.S. and F.S.; Methodology, L.O.S.S., F.H., Y.D.; Software, Y.H.O. and M.J.A.-F.; Validation, Y.H.O. and F.S.; Formal analysis, M.J.A.-F.; Investigation, M.J.A.-F., L.O.S.S., F.H., Y.D.; Resources, Y.H.O. and F.S.; Data curation, M.J.A.-F.; Writing-original draft preparation, M.J.A.-F.; Writing-review and editing, Y.H.O.; Visualization, M.J.A.-F.; Supervision, F.S.; Project administration, L.O.S.S. and M.J.A.-F.; Funding acquisition, Y.H.O.

Funding: This research received no external funding.

Conflicts of Interest: The authors declare no conflict of interest.

\section{References}

1. Rosamond, W.; Flegal, K.; Furie, K.; Go, A.; Greenlund, K.; Haase, N.; Hailpern, S.M.; Ho, M.; Howard, V.; Kissela, B.; et al. Heart disease and stroke statistics-2008 update: A report from the American Heart Association Statistics Committee and Stroke Statistics Subcommittee. Circulation 2008, 117, e25. [PubMed]

2. Nichols, M.; Townsend, N.; Scarborough, P.; Rayner, M. Cardiovascular disease in Europe 2014: Epidemiological update. Eur. Heart J. 2014, 35, 2950. [CrossRef] [PubMed]

3. American Heart Association. Heart Disease and Stroke Statistics-2018 Update: A Report From the American Heart Association. Circulation 2018, 137, e67.

4. The George Institute for Global Health. Reducing the burden of Cardiovascular Disease in Indonesia: Evidence Review. Available online: https://www.georgeinstitute.org/sites/default/files/reducing-the-burdenof-cvd-in-indonesia-evidence-review.pdf (accessed on 30 June 2019).

5. Vasa, M.; Ficht, L.; Scherer, S.; Aicher, A.; Adler, K.; Urbich, C.; Martin, H.; Zeiher, A.M.; Dimmeler, S. Number and migratory activity of circulating endothelial progenitor cells inversely correlate with risk factors for coronary artery disease. Circ. Res. 2001, 89, E1-E7. [CrossRef] [PubMed]

6. Oktaviono, Y.H.; Sargowo, D.; Widodo, M.A.; Dirgantara, Y.; Chouw, A.; Sandra, F. Proliferation of Peripheral Blood-derived Endothelial Progenitor Cells from Stable Angina Subjects. Indones Biomed. J. 2014, 6, 91-96. [CrossRef] 
7. Werner, N.; Wassmann, S.; Ahlers, P.; Schiegl, T.; Kosiol, S.; Link, A.; Walenta, K.; Nickenig, G. Endothelial progenitor cells correlate with endothelial function in patients with coronary artery disease. Basic Res. Cardiol. 2007, 102, 565-571. [CrossRef] [PubMed]

8. Loomans, C.J.; De Koning, E.J.; Staal, F.J.; Rabelink, T.J.; Zonneveld, A.J. Endothelial progenitor cell dysfunction in type 1 diabetes: Another consequence of oxidative stress? Antioxid. Redox Signal. 2005, 7, 1468-1475. [CrossRef]

9. Rehman, J.; Li, J.; Orschell, C.M.; March, K.L. Peripheral blood endothelial progenitor cells are derived from monocyte/macrophages and secrete angiogenic growth factors. Circulation. 2003, 107, 1164-1169. [CrossRef]

10. Widowati, W.; Sardjono, C.T.; Wijaya, L.; Laksmitawati, D.R.; Sandra, F. Extract of Curcuma longa L. and (-)-Epigallo Catechin-3-Gallate Enhanced Proliferation of Adipose Tissue-derived Mesenchymal Stem Cells (AD-MSCs) and Differentiation of AD-MSCs into Endothelial Progenitor Cells. J. USA-China Med. Sci. 2012, 9, 22-29. [CrossRef]

11. Widowati, W.; Wijaya, L.; Laksmitawati, D.R.; Widyanto, R.M.; Erawijantari, P.P.; Fauziah, N.; Bachtiar, I.; Sandra, F. Tea Flavonoids Induced Differentiation of Peripheral Blood-derived Mononuclear Cells into Peripheral Blood-derived Endothelial Progenitor Cells and Suppressed Intracellular Reactive Oxygen Species Level of Peripheral Blood-derived Endothelial Progenitor Cells. Nat. Prod. Sci. 2016, 22, 87-92.

12. Lucchesi, D.; Russo, R.; Gabriele, M.; Longo, V.; Del Prato, S.; Penno, G.; Pucci, L. Grain and bean lysates improve function of endothelial progenitor cells from human peripheral blood: Involvement of the endogenous antioxidant defenses. PLoS ONE 2014, 9, 10. [CrossRef] [PubMed]

13. Kong, B.J.; Han, S.S.; Ha, J.H.; Park, S.N. Antioxidant Activities of Ipomoea batatas L. Lam. (Purple Sweet Potato) Extracts Cultured in Korea. J. Soc. Cosmet. Sci. Korea 2014, 40, 423-430.

14. Fiorito, C.; Rienzo, M.; Crimi, E.; Rossiello, R.; Balestrieri, M.L.; Casamassimi, A.; Muto, F.; Grimaldi, V.; Giovane, A.; Farzati, B.; et al. Antioxidants increase number of progenitor endothelial cells through multiple gene expression pathways. Free Radic Res. 2008, 42, 754-762. [CrossRef] [PubMed]

15. Parzonko, A.; Oświt, A.; Bazylko, A.; Naruszewicz, M. Anthocyans-rich Aronia melanocarpa extract possesses ability to protect endothelial progenitor cells against angiotensin II induced dysfunction. Phytomedicine. 2015, 22, 1238-1246. [CrossRef] [PubMed]

16. Iordache, F.; Iordache, C.; Pop, A.; Lupu, M.; Andrei, E.; Buzila, C.; Maniu, H. Effects of plant lectin and extracts on adhesion molecules of endothelial progenitors. Cent. Eur. J. Biol. 2011, 6, 330-341. [CrossRef]

17. Kano, M.; Takayanagi, T.; Harada, K.; Makino, K.; Ishikawa, F. Antioxidative activity of anthocyanins from purple sweet potato, Ipomoea batatas cultivar Ayamurasaki. Biosci. Biotechnol. Biochem. 2005, 69, 979-998. [CrossRef] [PubMed]

18. Teow, C.C.; Truong, V.D.; McFeetersa, R.F.; Thompsona, R.L.; Pecotab, K.V.; Yenchob, G.C. Antioxidant activities, phenolic and $\beta$-carotene contents of sweet potato genotypes with varying flesh colours. Food Chem. 2007, 103, 829-838. [CrossRef]

19. Sun, C.; Fan, S.; Wang, X.; Lu, J.; Zhang, Z.; Wu, D.; Shan, Q.; Zheng, Y. Purple sweet potato color inhibits endothelial premature senescence by blocking the NLRP3 inflammasome. J. Nutr. Biochem. 2015, 26, 1029-1040. [CrossRef]

20. Jawi, I.; Indrayani, W.; Arijana, I.; Subawa, A.; Suprapta, D. Aqueous extratc of purple sweet potato increased SOD-2 and SOD-3 expression on human umbilical vein endothelial cells in vitro. J. Biol. Agric. Health 2016, 6, 103-110.

21. Yu, J.; Tu, Y.K.; Tang, Y.B.; Cheng, N.C. Stemness and transdifferentiation of adipose-derived stem cells using L-ascorbic acid 2-phosphate-induced cell sheet formation. Biomaterials 2014, 35, 3516-3526. [CrossRef]

22. Sandra, F.; Oktaviono, Y.H.; Widodo, M.A.; Dirgantara, Y.; Chouw, A.; Sargowo, D. Endothelial Progenitor Cells Proliferated via MEK-dependent p42 MAPK Signaling Pathway. Mol. Cell Biochem. 2015, 400, 201-206. [CrossRef] [PubMed]

23. Cao, N.; Liu, Z.; Chen, Z.; Wang, J.; Chen, T.; Zhao, X.; Ma, Y.; Qin, L.; Kang, J.; Wei, B.; et al. Ascorbic acid enhances the cardiac differentiation of induced pluripotent stem cells through promoting the proliferation of cardiac progenitor cells. Cell Res. 2012, 22, 219-236. [CrossRef] [PubMed]

24. Mohamed, M.S.; Chen, Y.; Yao, C.L. A serum-free medium developed for in vitro expansion of murine intestinal stem cells. Biotechnol. J. 2014, 9, 962-970. [CrossRef] [PubMed] 
25. Balestrieri, M.L.; Schiano, C.; Felice, F.; Casamassimi, A.; Balestrieri, A.; Milone, L.; Servillo, L.; Napoli, C. Effect of low doses of red wine and pure resveratrol on circulating endothelial progenitor cells. J. Biochem. 2008, 143, 179-186. [CrossRef] [PubMed]

26. Fleissner, F.; Thum, T. Critical Role of the Nitric Oxide/Reactive Oxygen Species Balance in Endothelial Progenitor Dysfunction. Antioxid. Redox Signal. 2011, 15, 933-948. [CrossRef] [PubMed]

27. Jiao, Y.; Jiang, Y.; Zhai, W.; Yang, Z. Studies on antioxidant capacity of anthocyanin extract from purple sweet potato (Ipomoea batatas L.). Afr. J. Biotechnol. 2012, 11, 7046-7054.

(C) 2019 by the authors. Licensee MDPI, Basel, Switzerland. This article is an open access article distributed under the terms and conditions of the Creative Commons Attribution (CC BY) license (http://creativecommons.org/licenses/by/4.0/). 